\title{
Comparison of Weibull and Probit Analysis in Toxicity Testing of Hunteria umbellata K Schum (Apocynaceae) Extract in Mice
}

\author{
Sunny A Osagie ${ }^{1}$, Ighodaro Igbe ${ }^{2^{*}}$ and Joseph E Osemwenkhae ${ }^{1}$ \\ ${ }^{1}$ Department of Mathematics, Faculty of Physical Sciences, ${ }^{2}$ Department of Pharmacology and Toxicology, Faculty of \\ Pharmacy, University of Benin, Benin City, Nigeria
}

\begin{abstract}
Purpose; Hunteria umbellata has been found to have therapeutic potentials in the treatments of diseases such as yaws, peptic ulcers, diabetes, piles and infertility in Nigeria; hence, the statistical analysis on the determination of acute toxicity of Hunteria umbellata was carried out in mice.

Methods; Data on the acute toxicity studies of the seed extract of Hunteria umbellata administered via the intraperitoneal route was analyzed using the two-parameter Weibull model.

Results; The median lethal dose $\left(L D_{50}\right)$ was $1.61 \mathrm{~g} / \mathrm{kg}$ of body weight. This result falls in the neighbourhood of the median lethal dose earlier obtained in previous reports.

Conclusion; The results show that Hunteria umbellata may be slightly toxic when administered intraperitoneally.
\end{abstract}

Keywords: Hunteria umbellata, Weibull model, Acute toxicity, Median lethal dose $\left(L D_{50}\right)$. 


\section{INTRODUCTION}

Many plants have been used as substitutes to orthodox medicines in Africa due to the ease of obtaining them in bushes and forests. These herbal medicines may be sources of substances with better therapeutic potentials than some currently used orthodox medicines [1]. The environment we live in is filled with abundant resources and chemicals endowed to humans by nature for beneficial uses. To explore the benefits of these resources, there is need to make contact with them via any route of exposure depending on the physical and chemical properties of the substance(s) of interest. This could be achieved through inhalation, skin absorption, ingestion or injection.

Hunteria umbellata K. Schum is a small tree of about 15-22 $\mathrm{m}$ in height with a dense evergreen crown [2] of great medicinal benefits and is found in West and Central Africa. In Nigeria, it is found in the rain forest zone of the southern part of the country with the local names, osu (Edo), erin (Yoruba) and nkpokiri (Ibo) [3]. The plant is also used for the treatment of yaws, peptic ulcers, diabetes, piles, dysmenorohea, fevers and infertility $[4,5,6,7]$ and inflammation [8,9]. It has been used in the treatment of various ailments in Nigeria and Ghana, especially the leaves, roots and bark [10]. The statistical study of the toxicity of this plant is necessary for gaining knowledge of its toxic effect in relation to its consumption by humans.

This present study was undertaken to statistically determine the acute toxicity of Hunteria umbellata extract administered to mice through intraperitoneal route with the aid of Weibull model and compare with probit analysis.

Various mathematical models have been used in the analyses of dose-response relationships to assess the toxic effects of chemical substances. These models range from very simple models to extremely complicated models for which the eventual functional forms cannot be easily expressed as single equations. Specifically, these models are (i) tolerance distribution models: log-probit, probit, Weibull, Mantel-Bryan models [11], (ii) mechanistic models: Hit and multistage models [12], (iii) time-to-tumor models: Lognormal, Weibull, Hatley - Sulken and multistage models [12,13], (iv) physiologically-based pharmacokinetic (PBPK) models [14,15], and (v) biologicallyBased Models: Moolgavkar-Venzon-Kundson (MVK) model [16] and Ellwein and Cohen model [17].

To determine the toxic effect of Hunteria Umbellata plant, the median lethal dose $\left(L D_{50}\right)$ of the two-parameter Weibull model is employed. The Weibull model as a tolerancedistribution model has been used extensively to predict time-to-failure of electrical and mechanical systems and it is more widely applied to dose-response relationships. It is capable of representing threshold and concave curves and sensitive to the shape of the dose-response curve. It also has the advantage of being able to incorporate a time-to-tumor function [13]

\section{EXPERIMENTAL}

\section{Plant material and extraction}

The ripe fruits of Hunteria umbellata were collected from Egor Local Government Area in Benin City, Nigeria. It was first identified by Professor Macdonald Idu of Department of Botany, Faculty of Life Sciences, University of Benin, Benin City, Nigeria and later authenticated by Forest Research Institute of Nigeria, Ibadan, where a sample with number FHl107618 was deposited.

The fresh ripe fruits of Hunteria umbellata were opened and the pulp removed. The seeds were squeezed out of the pulp. The pulp was dried in the sun for a week and turned to powder with the aid of a grinder. The powdered material $(400 \mathrm{~g})$ was boiled with $1,500 \mathrm{ml}$ of distilled water for $30 \mathrm{~min}$ to obtain the aqueous extract. The extract was filtered, concentrated under pressure in a 
rotar vapor at $68{ }^{\circ} \mathrm{C}$ and dried in an oven set at $40{ }^{\circ} \mathrm{C}$ for $48 \mathrm{~h}$ (yield: $21 \%$ ). The dried aqueous extract was preserved in clean glass containers at $4{ }^{\circ} \mathrm{C}$ in a refrigerator until use.

\section{Acute toxicity study using probit analysis}

Overnight-fasted Swiss albino mice (17-23 g) of either sex obtained from the Laboratory Animal Centre, College of Medicine, University of Lagos, Nigeria were used for the study. The animals were divided into five groups of five animals each. Groups $A$ to $D$ received $1.4,1.6,1.8$ and $2.0 \mathrm{~g} / \mathrm{kg}$ of the extract, respectively, while group $\mathrm{E}$ received distilled water intraperitoneally. The number of deaths that occurred in each group was determined, and using probit analysis, the $\mathrm{LD}_{50}$ was determined by hand calculation.

Method of analysis of acute toxicity using the Weibull model

Suppose $X$ is a response data with data points $x, x_{2}, \ldots, x_{n}$, then the two parameter Weibull distribution is defined as in Eq 1

$f(x)=\left(\frac{\alpha}{\beta}\right)\left(\frac{x}{\beta}\right)^{\alpha-1} \exp -\left(\frac{x}{\beta}\right)^{\alpha}, \alpha \beta>0$

where $x=\log _{e}$ (dose) and dose is the total amount of a substance administered or taken up by test subject(s). $\alpha$ and $\beta$ are shape and scale parameters respectively.

In estimating the shape and scale parameters of the Weibull model given as in Eq 2.

$$
p(d)=1-\exp \left(-\beta d^{\alpha}\right)
$$

It is convenient to estimate them from Eq 1. Thus, we employed the maximum likelihood estimation (MLE) method for $\beta$ and the least square estimation for $\alpha$ respectively.

The likelihood function of (1) with respect to $\beta$ is

$$
\begin{gathered}
L(\beta)=\prod_{i=1}^{n}\left[\left(\frac{\alpha}{\beta}\right)\left(\frac{x_{i}}{\beta}\right)^{\alpha-1} \exp -\left(\frac{x_{i}}{\beta}\right)^{\alpha}\right] \\
=\left(\frac{\alpha}{\beta}\right)^{n}\left[\sum_{i=1}^{n}\left(\frac{x_{i}}{\beta}\right)^{\alpha-1} \exp -\left(\frac{x_{i}}{\beta}\right)^{\alpha}\right]
\end{gathered}
$$

The log-likelihood of (3) is

$\Delta=\log _{e} L(\beta)=n \log _{e} \alpha-n \log _{e} \beta+\sum_{i=1}^{n}\left[\left(\frac{x_{i}}{\beta}\right)^{\alpha-1} \exp -\left(\frac{x_{i}}{\beta}\right)^{\alpha}\right]$

Taking partial derivatives of Eq 4 with respect to $\alpha$ and $\beta$ and equating the resulting derivatives to zero, we obtain and

$$
\begin{aligned}
& \hat{\beta}=\left[\frac{1}{n} \sum_{i=1}^{n} x_{i}^{\hat{\alpha}}\right]^{1 / \hat{\alpha}} \\
& \hat{\alpha}=\frac{\log _{e}\left[\frac{1}{n} \sum_{i=1}^{n} x_{i}^{\hat{\alpha}}\right]-1}{\left[\frac{1}{n} \sum_{i=1}^{n} x_{i}-\sum_{i=1}^{n}\left(\log _{e} x_{i}\right)-n \log _{e}\left[\frac{1}{n} \sum_{i=1}^{n} x_{i}^{\hat{\alpha}}\right]^{1 / \hat{\alpha}}\right.}
\end{aligned}
$$

From Eq 6 , the estimate of $\alpha$ would be difficult to obtain. Hence, the necessity for estimation of $\alpha$ via the least squares estimation (LSE) method. This is done by the consideration of the cdf of the two-parameter Weibull distribution.

The cdf of the two-parameter Weibull distribution is given as:

$$
F(x)=1-\exp -\left(x \beta^{-1}\right)^{\alpha}, \alpha, \beta \geq 0
$$

where $x=\log _{e}($ dose $)$

Taking natural logarithm of Eq 7 gives Eq 8 .

$\log _{e}\left\{-\log _{e}[1-F(x)]\right\}=-\alpha \log _{e} \beta+\alpha \log _{e} x$

This gives a linear equation of the form $y=a+b x$

From Eq 8 , the estimate of $\alpha$ is 
$\hat{\alpha}=\frac{\sum_{i=1}^{n}\left(\log _{c} x_{i}\right)\left(\log _{e}\left\{-\log _{e}\left[-F\left(x_{i}\right)\right]\right)+\frac{1}{n}\left[\sum_{i=1}^{n}\left(\log _{c} x_{i}\right) \sum_{i=1}^{n} \log _{e}\left\{-\left(\log _{e}\left[1-F\left(x_{i}\right)\right)\right\}\right]\right.\right.}{\sum_{i=1}^{n}\left(\log _{e} x_{i}\right)^{2}-\frac{1}{n}\left(\sum_{i=1}^{n} \log _{e} x_{i}\right)^{2}}$

where $F\left(x_{i}\right)$ is estimated as $\frac{\operatorname{rank}\left(x_{i}\right)}{n+1}$.

Equations 5 and 9 give the explicit mathematical formulae for the values of the estimates of $\alpha$ and $\beta$ [18] from which the $\mathrm{LD}_{50}$ of the Weibull model is calculated.

Also, the median lethal dose for the Weibull model is given as in Eq 10.

$$
\hat{x}_{50}=\hat{\beta}\left(\log _{e} 2\right)^{1 / \hat{\alpha}}
$$

For the purpose of comparison, Relative Error is employed and defined as:

$E r r_{\text {Rel. }}=\left|\frac{L D_{50}(\text { weibull })-L D_{50}(\text { probit })}{L D_{50}(\text { probit })}\right|$,

where $E R_{\text {Rel }}$ lies bwteeen 0 and 1 .

For the purpose of the study, we set a benchmark at 0.5 and made use of the following criteria for comparison:

Criterion I: If $\operatorname{Err}_{\text {Rel. }}<0.5$, the Weibull model should be used to obtain the acute toxicity ,Criterion II: If $E r r_{\text {Rel. }}=0.5$, any of Weibull or probit model can be used,

Criterion III: If $0.5<\mathrm{Err}_{\text {Rel }}<1$, the probit model should be used.

\section{RESULTS}

In the determination of $\mathrm{LD}_{50}$, Table 1 shows the various doses used in the acute toxicity studies and their corresponding log doses, mortality ratio of the animals and their corresponding probit values $(n=5$ per group).

It was observed that the lethal dose at $50 \%$ $\left(L_{50}\right)$ gave $1.66 \mathrm{~g} / \mathrm{kg}$ (1660 mg/kg) using probit analysis. The estimates of shape and scale parameters of Weibull model from (5) and (9) are obtained as

$$
\hat{\alpha}=2.6946 \text { and } \hat{\beta}=0.5491
$$

Also,

$$
\hat{x}_{50}=\log _{e}\left(L \hat{D}_{50}\right)=0.4793
$$

It follows that

$L \hat{D}_{50}=1.6149 \mathrm{~g} / \mathrm{kg}(1614.9 \mathrm{mg} / \mathrm{kg})$

Also, from Eq (11), $\mathrm{Err}_{\text {Rel. }}=0.02717$

Table 1: Acute toxicity data for $H$. umbellata seed extract in mice

\begin{tabular}{ccccc}
\hline $\begin{array}{l}\text { Dose } \\
(\mathbf{g} / \mathbf{k g})\end{array}$ & $\begin{array}{l}\text { Log } \\
\text { dose }\end{array}$ & $\begin{array}{l}\text { Mortality } \\
\text { ratio }\end{array}$ & $\begin{array}{l}\% \\
\text { Mortality }\end{array}$ & Probit \\
\hline 1.4 & 0.146 & $0 / 5$ & 0 & 3.040 \\
1.6 & 0.204 & $3 / 5$ & 60 & 5.253 \\
1.8 & 0.255 & $4 / 5$ & 80 & 5.841 \\
2.0 & 0.301 & $5 / 5$ & 100 & 6.960 \\
\hline
\end{tabular}

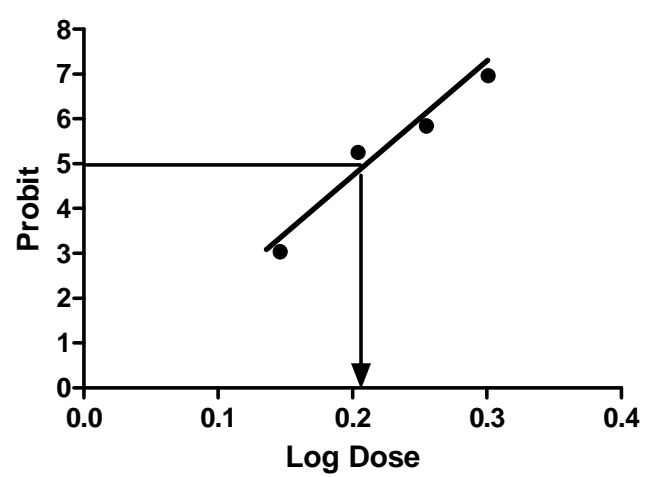

Fig 1: Intraperitoneal acute toxicity of $H$. umbellata seed extract indicating the line of regression. Median lethal dose $\left(\mathrm{LD}_{50}\right)$ using probit analysis is $1.66 \mathrm{~g} / \mathrm{kg}$.

\section{DISCUSSION}

Toxic effects in the biological system are not produced by chemical agents unless that chemical agent or its metabolic breakdown (biotransformation) reaches appropriate site in the body at a concentration and a length of time sufficient enough to produce a toxic manifestation. Two major factors that influence toxicity as it relates to exposure situation for a specific chemical are the routes of exposure, duration and frequency of exposure. Toxic agents generally produce the greatest effect and rapid response when 
given intravenously. An approximately descending order of effectiveness for other routes would be inhalation, intraperitoneal, subcutaneous, intramuscular, intradermal, oral and dermal. Earlier reports have shown that aqueous fruit pulp extract of Hunteria umbellata is not toxic orally [9] hence the need to further determine its acute toxicity profile via another route of administration. Acute toxicity study using the Weibull model gave a median lethal dose of $1.6149 \mathrm{~g} / \mathrm{kg}$ as compared to the probit analysis median lethal dose of $1.66 \mathrm{~g} / \mathrm{kg}$. This indicates that $L D_{50}$ obtained by the weibull model was comparable to that of conventional methods like probit analysis. The results obtained from these two models indicate that Hunteria umbellata plant is slightly toxic [19]. In addition, the American Society for Testing and Materials [20], stated that any chemical substance with $\mathrm{LD}_{50}$ value less than $2 \mathrm{~g} / \mathrm{kg}$ but greater than $1 \mathrm{~g} / \mathrm{kg}$ could be considered to be slightly toxic. The result obtained in the determination of the acute toxicity of Hunteria umbellata suggests it is slightly toxic on acute exposure intraperitoneally.

\section{CONCLUSION}

The Weibull $L_{50}$ value for Hunteria umbellata was $1.6149 \mathrm{~g} / \mathrm{kg}$ with relative error of 0.02717 . Since the relative error lies in Criterion I, it implies that the Weibull model gives a better result in obtaining $L D_{50}$ than probit model in this study.

\section{ACKNOWLEDGEMENT}

The authors wish to thank Dr D Okuonghae for his contributions to the development of this paper.

\section{REFERENCES}

1. Wang $Y$, Wang $X$, Cheng $Y A$. A Computational approach to botanical drug design by Modelling quantitative compositions activity relationship, Chem. Bio. Drug Design, 2006; 68: 168-172.
2. Oliver-Bever B. Medicinal Plants in tropical West Africa. Cambridge University Press, Cambridge, 1986; 60-62.

3. Boone MJ. Hunteria umbellata (K.Schum) Hallier F.In:Schmelzer GH \& Gurib-Fakim A (Editors) Prota II:Medicinal plants/Plantes medicinales (CD-Rom).PROTA Wageningen. Netherland, 2006

4. Raman A, Mallam V. Enhanced in vitro activity of glucokinase enzyme in the presence of Hunteria umbellata seeds, a traditional Nigerian treatment for diabetes J. Pharm. Pharmocol., 1994; 46: 1046-1049

5. Eluyoba $A A$. Female Infertility in the Lands of traditional birth attendants in South-Western Nigeria. Fiitoterapia, 1995; 66: 239-248.

6. Falodun $A$, Nworgu ZAM, Ikponmwonsa $M O$. Phytochemical components of Hunteria umbellata (K.Schum) and its effect on isolated non-pregnant rat uterus in oestrus. Pak. J. Pharm. Sci., 2006; 19: 256-258

7. Igbe I, Ching FP, Eromon A. Anti-Inflammatory activity of Aqueous fruit pulp extract of Hunteria umbellata K. Schum in Acute and Chronic Inflammation Acta Pol Pharm Drug Res, 2010; 67: 81-85

8. Gills LS. Ethnomedical uses of plants in Nigeria. Benin City. Uniben Press. 1992: $p 134$.

9. Igbe I, Ozolua RI, Okpo SO, Obasuyi O. Antipyretic and Analgesic effects of the Aqueous Extract of the Fruit Pulp of Hunteria umbellata $K$. Schum (Apocynaceae). Trop J Pharm Res, 2010; 8: 331-336.

10. Ibeh IN, Idu M, Ataman JE. Toxicological assessment of Abeere seed (Hunteria umbellata K. Schum). J Med Biomed Res, 2005; 4: 44-48

11. Christensen ER. Dose-response functions in Aquatic toxicity testing and the Weibull model. Ecol Modelling 1984; 22: 13-20

12. Hoel DG. Mathematical dose-response models and their applications to risk estimation. In: Methods for Estimating Risk of Chemical Injury: Human and Nonhuman Biota And Ecosystems, Scope/SGOMSEC 2. John Wiley and Sons, 1985; 347-359

13. Szymczak W, Szadkowska - Stanczyk I. Cancer Risk Assessment: Present and Future. International J Occup Medicine Env Health 2005; 18: 207-223

14. Reddy MB, Yang RSH, Clewell HJ III and Andersen ME (2005) Physiologically - Based Pharmacokinetic (PBPK) Modelling: Science and Applications John Wiley and Sons. pp. 420

15. Chiu WA, Barton HA, DeWoskin RS, Schlosser P. Thompson CM, Sonawane B, Lipscomb JC, Krishnan K. Review: Evaluation of Physiologically - Based Pharmacokinetic Models for use in risk assessment. J Applied Toxicol, 2007; 27: $218-237$

Trop J Pharm Res, December 2012;11 (6):937 


\section{Osagie et al}

16. Moolgavkar SH. A two-stage carcinogenesis model for risk assessment. Journal of Cell Biol. Toxicol, 1989; 5: $445-460$

17. Ellwein LB, Cohen SM. A Cellular Dynamics model of experimental bladder cancer: Analysis of the effect of sodium saccharin in the rat. J. Risk Analysis, 1988; 8: $215-221$

18. Osemwenkhae JE, Osagie SA. Mathematical Modelling of the Gradual Aging of Systems using the Weibull hazard function. J. Nig. Assoc. Math. Phys, 2010; 17: 73-76
19. Loomis TA. Essentials of Toxicology. Ed 3, Lea and Febizer, Philadelphia. 1978; $p 198$

20. American Society for Testing and Materials. Standard Test Method for Estimating Acute Oral Toxicity in Rats. American Society for Testing and Materials E1163 87, Philadelphid, USA, 1987. 